\title{
Nation branding in the COVID-19 era: South Korea's pandemic public diplomacy
}

\author{
Seow Ting Lee ${ }^{1} \cdot$ Hun Shik Kim ${ }^{2}$
}

Revised: 12 June 2020 / Accepted: 2 October 2020 / Published online: 15 October 2020

(c) Springer Nature Limited 2020

\begin{abstract}
In a global pandemic, public health outcomes are not the only variables at stake. Also at stake are countries' nation brands and influence, which hinge on how a country responded to the crisis. Based on a case study of a middle power, South Korea, one of the more successful COVID-19 national responses so far, we offer an exploratory conceptual explication of pandemic public diplomacy that is grounded in a normative framework of substance, information, trust, collaboration, and mutual benefit. Sentiment analyses of social media and international news media suggest that the country is perceived as a model on how to cope with the pandemic by international audiences. Unlike other public diplomacy contexts, pandemic public diplomacy challenge conventional assumptions about public diplomacy and nation branding. As nation-states confront a common enemy, how public diplomacy and nation branding play out in COVID-19-arguably the most socially disruptive event in modern history - helps to shed light on the dynamics of mutual interdependence in an interconnected yet competitive world fraught with fear, uncertainty, and information deficiency.
\end{abstract}

Keywords Pandemic public diplomacy · Pandemic · COVID-19 · Coronavirus · Health $\cdot$ Crisis $\cdot$ Public diplomacy $\cdot$ Soft power $\cdot$ Nation brand $\cdot$ Nation branding $\cdot$ Sentiment analysis $\cdot$ South Korea

\section{Introduction}

The global health crisis precipitated by COVID-19 has ushered in a new chapter in public diplomacy, as border closures, lockdowns, and social distancing become the norm across the globe. As nations struggle to contain COVID19 , in a pandemic fraught with life-and-death decisions and uncertainties about shifting economic, social, and political power, some countries are viewing the crisis as a strategic opportunity to elevate their nation brand in the eyes of the world. Nations can close their borders, but confronted with the common enemy of COVID-19, public diplomacy may

Seow Ting Lee

seowting.lee@colorado.edu

Hun Shik Kim

hunshik.kim@colorado.edu

1 Department of Advertising, Public Relations, and Media Design, University of Colorado at Boulder, 1511 University Avenue, UCB 478, Boulder, CO 80309, USA

2 Department of Journalism, University of Colorado at Boulder, 1511 University Avenue, UCB 478, Boulder, CO 80309, USA very well offer some nations an opportunity for reaping the spoils of war, by way of an expanded soft power profile on the world stage.

Pandemics are atypical contexts characterized by outbreaks of infectious diseases affecting individuals and communities over a wide geographical area. With many "unknowns" as well as ebbs and flows, pandemics are nonlinear and challenge conventional assumptions (Carlsen and Glenton 2016; Lee and Basnyat 2013; Vaughan and Tinker 2009). As a global pandemic, COVID-19 presents a compelling context for investigating the intersections of public diplomacy and nation branding. Studies have addressed the increasing complementarity of public diplomacy and nation branding in contemporary diplomacy (Anholt 2007; Potter 2018; Singh and Macdonald 2017). Public diplomacy, as nation-states' strategic endeavors to promote its national interest, seeks to influence public attitudes on the formation and execution of a country's foreign policies by a wide range of means including ideas, practices, values, culture, art, food, music, media, language, and economic aid. At the heart of public diplomacy lies the concept of soft power or "the ability to affect others to obtain the outcomes one wants through attraction rather than coercion or payment" 
(Nye 2008, p. 94). "The resources that produce soft power arise...from the values... a country expresses in its culture, in the examples it sets by its internal practices and policies, and in the way it handles its relations with others. Public diplomacy is an instrument that governments use to mobilize these resources to communicate with and attract the publics of other countries" (p. 94).

Anholt (2007) incorporated public diplomacy into nation branding, presenting public diplomacy and nation branding as complementary and mutually reinforcing foundations of a nation's international communication. How public diplomacy and nation branding play out under COVID-19arguably the most socially disruptive event in modern history-could offer tremendous lessons in understanding the dynamics and tensions of mutual interdependence in an interconnected yet competitive world.

The use of health aid or "medical diplomacy" for public diplomacy is not new. With the focus of soft power on fostering a favorable country image and likeability, "few areas of diplomatic goodwill connect more with the humanitarian nature of international citizenship than medical assistance" (Bier and Arceneaux 2020). Cuba, for instance, has actively deployed health aid for public diplomacy (Bier and Arceneaux 2020; Gomez 2014; Groll 2013). For 60 years, the socialist state-lacking in natural resources and isolated by the U.S.- - has sent health supplies - along with its army of well-trained doctors and nurses-to natural disasters and pandemics overseas. Cuba's first foray into medical diplomacy was in 1960 in Chile's earthquake. In the 2014 Ebola outbreak in West Africa, Cuba sent health workers to Liberia, Sierra Leone, and Congo, earning the praise of thenWHO director Dr. Margaret Chan, who pointedly reminded other countries that money and materials alone are not enough to fight Ebola (Gomez 2014).

Unlike previous pandemics in more recent memory, COVID-19 is striking in its global scope, spreading to every continent to upend societies and dramatically alter everyday life across the globe. Comparatively, the 2009 H1N1, the 2012 Middle East Respiratory Syndrome (MERS), and the 2003 Severe Acute Respiratory Syndrome (SARS) were more limited and regional in scope, although sporadic cases were transmitted outside the areas where outbreaks first emerged.

COVID-19 first emerged in late 2019 in Wuhan, China. It was soon confirmed as a new coronavirus associated with a family of viruses that cause respiratory infections ranging from the common cold to more severe forms such as MERS and SARS. On March 11, the WHO declared COVID-19 a pandemic. In China alone, by April 2020, 4,636 people died, mostly in Hubei province, where Wuhan is located. As of June 10, 2020, WHO data showed that COVID-19 has spread to more than 216 countries and territories, with over 7.2 million cases and 412,000 deaths (Coronavirus disease
COVID-19 pandemic n.d.). The COVID-19 spread have shown different trajectories in different countries. In countries that were hit hard earlier, including China, the U.S., the U.K., France, Italy, Spain, and South Korea, the number of new cases has slowed. However, in other countries especially in South America, Africa, and the Middle East, the transmission rate continues to peak.

Our study, focusing on South Korea, applies the conceptual lenses of public diplomacy and nation branding. South Korea is among a handful of Asian countries-including China, Taiwan, Hong Kong, and Vietnam-that have applied a containment approach against COVID-19. This approach has reaped significant success, with a number of Western healthcare systems turning to Asian governments including South Korea as "examples of forceful measures of containment" that are effective for battling COVID-19 (Attias 2020).

In pandemics, public health outcomes are not the only variables at stake. Also at stake are countries' nation brands and influence. Snyder and Sindyukov (2020) suggested that countries that have responded relatively effectively (e.g., South Korea and Taiwan) find themselves with a larger voice in issues or platforms where they might not have held as much sway before. For instance, South Korea's "capable mitigation techniques have transformed the country's brand from tech know-how into exemplary public health and citizen cooperation" (Attias 2020) and its "robust strategy to tackle the outbreak seems to burnish its national reputation" (Wang 2020).

\section{Nation branding as a process and an outcome}

Nation branding is concerned with a country's whole image on the international stage, covering political, economic, and cultural dimensions (Anholt 2007; Fan 2006; Quelch and Jocz 2004). Fan (2010) defines nation branding as "a process by which a nation's images can be created or altered, monitored, evaluated and proactively managed in order to enhance the country's reputation among a target international audience" (p. 101). Anholt (2007) views nation branding as a metaphor for how effectively countries compete with each other for favorable perception, be it with regard to exports, governance, tourism, investment and immigration, culture and heritage, or people. It is seen as a powerful political tool, especially among small, peripheral nations or middle-power nations eager to strengthen their positions and to compete against the economic, cultural, financial, or military clout of superpowers (Volcic and Andrejevic 2011). Traditionally, tourism promotion has dominated the nation branding of small and middle-power nations (e.g., Avraham 2018; Fan 2006; Scott et al. 2011). 
A nation brand is inherently a complex, multifaceted construct. It is about how a country is seen by others, and comprises "a complex bundle of images, meanings, associations and experiences in the minds of people (Fan 2010, p. 98). Dinnie (2008) defines nation brands as "the unique, multi-dimensional blend of elements that provide the nation with culturally grounded differentiation and relevance for all of its target audiences" (p. 15). As a "mental image of the country held by foreign people," a nation brand is "the total sum of all perceptions of a nation in the minds of international stakeholders, which may contain some of the following elements: people, place, culture/language, history, food, fashion, famous faces (celebrities), global brands and so on" (Fan 2010, p. 98). Every nation has a "brand," with or without any efforts in nation branding, because "each country has a certain image to its international audience, be it strong or weak, current or outdated, clear or vague" (Fan 2006, p. 12).

\section{COVID-19 and the nation brand}

Within the context of COVID-19, the notion that countries have their unique nation brands is not far-fetched at all; in the minds of international audiences, Country A may be a COVID-19 success story while Country B may be associated with poor containment measures, insufficient test kits, or high death rates. Arguably, a global pandemic situation-with its immeasurable burden of deaths and scope of devastation, and no vaccine in sight-is a perfect public diplomatic space for nation branding as "a strategic, policy-making approach, designed to help places build on the strengths that will earn them a better reputation" (Anholt 2007, p. 4).

Our study fills a gap in the nation branding and public diplomacy literature, which has yet to focus on COVID19. Given the novelty and currency of COVID-19, it is not surprising that no published research exists. A number of studies have addressed public diplomacy in times of crisis or conflict, but none have examined public diplomacy and nation branding in the context of a pandemic. There is a body of literature on place branding of tourist destinations in crisis and conflict (Avraham 2009, 2018) as well as countryspecific studies on Israel (Avraham 2009); Egypt (Avraham 2016); and Nepal (Ketter 2016). Other crisis-focused studies include the Danish government's efforts to rebrand the country after the Denmark Cartoon Crisis (Rasmussen and Merkelsen 2014); Beijing's public diplomacy to repair the country's "Made in China" controversy (Cai et al. 2009); the U.S. government's efforts to repair its image after the 2008 financial crisis (Chua and Pang 2012); and the Greek government's rebranding of the country after its financial crisis (Vaxevanidou 2016, 2017).

The above studies share a crisis communication framework, by focusing on repairing reputational damage or overcoming weaknesses in a country's nation brand. In contrast, we focus on nation building as "a strategic, policy-making approach, designed to help places build on the strengths that will earn them a better reputation" (Anholt 2007 , p. 4). In this context, our study is not about addressing a reputational deficit or nation brand weakness, but rather how a country-based on success with COVID-19-deploys public diplomacy to bolster what its government views as immediate strengths in a fast-evolving global pandemic.

\section{COVID-19 in South Korea}

COVID-19 was first detected in South Korea on January 20, 2020 through an imported case from China (Kim 2020a). Three days later, the country confirmed its first South Korean national to be infected: a man who had returned after working in Wuhan. The number of cases grew as travelers continued to enter South Korea from China. Community infections also contributed to the spread. On February 18, the number of cases jumped dramatically after the Korea Centers for Disease Control and Prevention (KCDC) identified a COVID-19 super-spreader who infected at least 142 people during a mass at the Shincheonji Church of Jesus in the city of Daegu (142 additional cases 2020).

By February 29, COVID-19 cases in South Korea exceeded 2000, with daily infections outpacing China's. By March 2, the number of confirmed cases doubled, exceeding 4200 with 22 people dead (476 additional cases 2020). About $60 \%$ of the cases originated from the Shincheonji cluster. Infected church members traveled to other cities, spreading the illness. By then, South Korea became one of the world's largest epicenters of COVID-19 outside China, leading at least 15 countries including the U.S., Japan, and Taiwan to impose travel restrictions on South Korea. Faced with a massive public health crisis, the government decided to focus on aggressive testing and extensive contact tracing (Kim 2020b). It demanded that Shincheonji turn over its membership list to identify thousands of church members, ordered them to self-isolate for 14 days (Thompson 2020), and traced patients' smartphone GPS data.

Within one month, the number of new daily cases flattened, with more recoveries than new infections. At the peak on February 29, the average number of new daily cases was 909. By April 1, it was fewer than 100. Unsurprisingly, South Korea's expedient COVID-19 response attracted the attention of public health officials elsewhere. In this context, South Korean President Moon Jae-in began to push a diplomatic campaign to elevate South Korea's image by leveraging his country's experience responding to the crisis (Attias 2020).

South Korea is not alone in its interest in nation branding during COVID-19. Emerging from a relatively successful COVID-19 mitigation by April 2020 after initial 
struggles, China launched a public diplomacy campaign to brand itself as a global health leader (Lancaster and Rubin 2020). The Chinese government, NGOs, and corporations sent medical teams, masks, and test kits to dozens of countries. Beijing resurrected the "Health Silk Road" moniker for nation branding, as it promoted its health leadership abroad to redeem its international image, scarred by controversy surrounding its early handling of the Wuhan outbreak (and unsavory associations with the initial naming of the novel coronavirus as "Wuhan virus").

Taiwan, viewed as a rogue province by Beijing, has also leveraged COVID-19 to boost its global standing. It shipped millions of face masks and other personal protective equipment (PPE) to the U.S., Canada, and its EU allies (Horton 2020; Jao 2020). Taiwan scored a public diplomacy triumph over China in May 2020 when U.S. White House staff including senior advisor Jared Kushner and White House press secretary Kayleigh McEnany were photographed wearing masks with "Made in Taiwan" stitched on them (McLaughlin 2020).

South Korea's COVID-19 response has not gone unnoticed. Attias (2020) suggested that COVID-19 has led to an improvement in South Korea's global image. Thompson (2020), referring to South Korea's COVID-19 exceptionalism, observed that "South Korea is not unique in its ability to bend the curve of daily cases; New Zealand, Australia, and Norway have done so, as well. But it is perhaps the largest democracy to reduce new daily cases by more than 90 percent from peak, and its density and proximity to China make the achievement particularly noteworthy." However, there is no published research on why and how South Korea "communicates with and attracts the publics of other countries" (Nye 2008, p. 94) within the conceptual framework of public diplomacy and nation branding in COVID-19. Our study seeks to answer the two research questions why and how South Korea utilized public diplomacy and nation branding in COVID-19, and to address a third: what are the outcomes of its efforts?

\section{Method}

To answer the three research questions, we utilized a case study approach (Yin 1984, 2002, 2014). Case studies offer an important method of learning about a complex phenomenon through extensive description and analysis of that instance in its contextual and natural settings (Harling 2012; Stake 1995; Yin 1984, 2002, 2014). Yin (2014) describes case study research as "an empirical inquiry that investigates a contemporary phenomenon (the 'case') in depth and within its real-world context" (p. 16). A case study is therefore particularly relevant here as we seek to answer why and how questions especially in a situation "when the boundaries between a phenomenon and context are not clear and the researcher has little control over the phenomenon and context" (Yin 2002, p. 13).

Case study research is primarily exploratory and explanatory. It seeks to understand an issue in real-life settings through triangulation of sources and methods to collect and analyze data. Consistent with the case study approach and its emphasis on triangulation, we collected and analyzed multiple sources of evidence including news media coverage, government communication (press statements, speech transcripts, and media interviews), and sentiment analyses of social media posts and international news reports. Yin (2014) presented the use of multiple data sources or multiple methods, which are brought together at some stage in a case study, as converging lines of inquiry. A significant strength of the case study method lies in its use of different data collection sources and methods in data gathering and data analysis to provide an important way of ensuring the validity of case study research (Johansson 2003). Case study research has undergone substantial methodological development in the last 40 years, evolving into a "pragmatic, flexible research approach, capable of providing comprehensive in-depth understanding of a diverse range of issues across a number of disciplines" (Harrison et al. 2017).

\section{Soft power assets vs. international perceptions}

Through our first research question, we analyzed why South Korea was determined to utilize public diplomacy and nation branding in the COVID-19 context. South Korea is one of the democratic countries in East Asia, with a population of 52 million people. Formerly a single nation that was annexed by Japan in 1910, the two Koreas have been divided along the 38th parallel by the United States and the Soviet Union since the end of WWII. The North and the South fought in the Korean War (1950-1953) that ended in an armistice agreement but without a peace treaty. Geographically, South Korea is flanked by two major powers, China and Japan. It is the world's 12th largest economy in terms of GDP, with $\$ 1.64$ trillion in 2019. South Koreans enjoy the world's fastest Internet speed, and the country is media-rich, with a plethora of TV, radio, and social media platforms. In the last two decades, South Korea has been known for its globally influential pop entertainment culture, including music (K-pop), TV dramas, cinema, and online gaming. Economic prosperity and universal health coverage through national health insurance have led to a rapid improvement in health outcomes (Asia Pacific Observatory n.d.).

What motivated South Korea to engage in public diplomacy and nation branding in the context of COVID-19? As a middle power, South Korea face challenges in terms of its 
visibility on the global stage. Middle powers are not superpowers in terms of cultural, military, or economic influence but nonetheless have a presence and influence on the international stage. The conceptual definition of middle power suggests a comparative place on an international hierarchy of states. States are middle powers "if they have less material resources than great powers, and if they exercise good global citizenship, work through international organizations and agencies, promote mediation and peaceful conflict resolution, and participate in peacekeeping operations" (Gilboa 2009 , p. 22). Global publics are either unaware of them, or hold negative opinions-thus requiring the need to secure global attention (Rockower 2012, p. 237).

According to Gilboa (2009) and Rockower (2012), middle-power countries such as South Korea, Taiwan, Malaysia, Australia, Mexico, and Thailand tend to adopt less conventional public diplomacy strategies such as promoting tourism, culinary tradition, fine arts and crafts, and folk and pop music to create better brand recognition and enhance global awareness of their respective cultures as a means to further nation brand status and soft power. Confronted by lack of awareness and limited resources, middle powers tend to focus on distinguishing themselves in areas of cultural diplomacy (Gilboa 2009).

According to the Soft Power 30 Index (SP30), in 2019, South Korea placed $19^{\text {th }}$ in its best showing since the index was launched in 2015 (Soft Power 30 Index 2019). In the Anholt-Ipsos Nation Brands Index of 2019, South Korea, as host of 2018 Winter Olympics, made solid gains to move up by three positions (Germany retains top 2019). Across all categories of the Soft Power 30 index, South Korea's lowest ranking is in its combined polling score, suggesting a gap between its soft power assets and perceptions of the outside world. It could do better by leveraging its strong digital assets and standing as a global innovation hub because "not everyone recognizes brands such as Samsung, LG, and Hyundai as Korean" (Soft Power 30 Index 2019).

In 2009, the country, under President Lee Myung-bak founded the country's first Presidential Council on Nation Branding. In Anholt's nation brand index of 2007, South Korea ranked 30th out of 35 countries (Kang 2008). In a 2008 speech marking the 60th anniversary of the country's founding, Lee said militant unions and violent protests are "the very first images that come to the minds of foreigners" when they think of Korea, adding that "[i]f the nation wants to be labeled an advanced country, it will be necessary to significantly improve its image and reputation" (Kang 2008). The council functioned as a general control tower on the country's nation branding activities, and charged with executing policies and programs, including the promotion of Korean culture, language, food, and digital technologies. It also focused on strengthening and expanding public-private partnerships and encouraging civic participation (Kim
2017). During its four-year-long operation, the council contributed significantly to the branding of Korean pop entertainment culture overseas. The global popularity and business successes of K-pop music and South Korean films are examples of how state-sponsored public-private collaboration has been applied to public diplomacy and nation branding (Hong 2014; Kim 2018). The council was disbanded after a change in government in 2013. Regardless, South Koreans' awareness of the importance of nation branding is unmistakable.

\section{Leveraging on existing strengths}

Nation branding is action-oriented; a country will have a hard time persuading others if its nation brand is without substance. Rhetoric alone cannot sell a nation brand in a pandemic, especially when it relates to a matter of fundamental import such as health. Four factors explain why South Korea could leverage on its existing strengths for nation branding in COVID-19.

\section{Learning from previous coronavirus outbreaks}

South Korea's successful response to the COVID-19 is a result of its experience with previous coronavirus-related outbreaks including SARS in 2003, and MERS in 2015. MERS spread quickly through health clinics and hospitals where infected patients had visited. Without adequate selfisolation and testing protocols in place, two MERS patients roamed through hospital wards and waiting rooms until they were tested positive. With 186 confirmed cases, 8 deaths and nearly 17,000 people placed under quarantine, South Korea's outbreak was the largest MERS outbreak outside of the Middle East (MERS outbreak, n.d.; Oh 2020).

After MERS, the government revamped much of the country's infectious-disease prevention legislation. To strengthen legal basis for coordination between the central and local governments, South Korea amended the Infectious Disease Control and Prevention Act. To expedite diagnostic testing during future public health emergencies, the Medical Devices Act was also amended to promote public-private medical partnerships and to establish emergency use authorization and licensing procedures for medical test kits-actions that now serve the country well when COVID19 hit (Oh 2020). In COVID-19, the government expedited the manufacturing and distribution of test kits ahead of many other countries. It procured test kits based on a coordinated transfer of public-funded technology to private biomedical firms, and next, established a mass testing system in which both public and private medical facilities played a central role (Kim 2020b). Early on, the government approved six South Korean biotech companies' mass production of 
COVID-19 test kits for public use. To encourage more people to test for COVID-19, the government launched a massive testing campaign via TV and social media. Many local governments made the test free. The government worked with public and private health care providers to run more than 600 testing centers, including "walk-through" and "drive-through" stations. Inspired by drive-through fast-food restaurants, the pop-up stations gave 10-minute tests without asking drivers to leave their cars (Thompson 2020) - a practice that was later adopted in other countries. These stations screened up to 20,000 people a day (Oh 2020) and results were sent via smartphone text messages within six hours (Attias 2020). By June 6, 2020, more than one million South Koreans were tested (Daily briefing 6/6, 2020). To expedite contact tracing, health authorities used warrantless access to CCTV footage, GPS data from smartphones, and credit card transaction records (Kim 2020b; Thompson 2020).

\section{A matter of comparison}

With substantive measures that were working, international news media started reporting on South Korea's response to COVID-19 as a model to emulate. The New York Times, suggesting that South Korea is ahead of the rest of the world in its COVID-19 response, praised the country's swift action, widespread testing, contact tracing, and citizens' voluntary support and participation (Fisher and Choe 2020). The Politico noted that South Korea's targeted testing and aggressive contact tracing was a successful example of how to contain COVID-19. The Atlantic attributed South Korea's successful response to three main strategies (1) fast and free testing, (2) expansive contact tracing technology, and (3) mandatory quarantine of the most severe cases (Thompson 2020).

South Korea's approach of testing, tracing, and treating infected people allowed the country to control COVID-19's spread without imposing aggressive lockdowns or complete travel bans that other countries deployed (Oh 2020). China, for instance, adopted draconian lockdowns of entire cities, raising the ire of some international audiences who viewed these moves as an extension of what many already perceived as Beijing's repressive regime and a poor humanrights record. South Korea, by contrast, took a less controversial approach. By avoiding lockdowns and travel bans, which South Korea could afford to ignore due to its successful "test-trace-treat" approach, it helped protect its image in the eyes of the world.

Seoul's response, when contrasted with what international audiences are witnessing, in their own countries and others, reinforces South Korea's positive image (Chung and Soh 2020; Ferrier and Hwang 2020; Fisher and Choe 2020; Thompson 2020). Martin (2020) observed that context is important; concurrently, the U.S. and European countries such as Italy, France, and the U.K. were overwhelmed by
COVID-19. In the U.K., officials were divided on whether to impose herd immunity (Freedman 2020). In the U.S., some politicians presented optimistic views of COVID-19 disappearing miraculously with warmer weather (Cohen 2020) as the country "entered this pandemic discombobulated, blundering, and hamstrung by our lack of readiness" (Thompson 2020), while blaming Beijing for failing to contain the virus within its borders (McNeil and Jacobs 2020; U.S. says 'significant evidence 2020). In this challenging period, and by contrast, the nation brand of South Korea shone even brighter.

While the government acknowledged the introduction of COVID-19 from China, it steadfastly kept its national borders open. Chinese visitors were still arriving in South Korea, when other countries banned them. Opposition lawmakers and the Korean Medical Association argued for restrictions on Chinese visitors, but the government insisted the real conduit of COVID-19 was South Koreans who traveled to China (Martin 2020). Regardless of the motive, this move-along with the success of aggressive contact tracing using digital technologies and testing - helped South Korea maintain a neutral stance in the face of international tensions over China's alleged culpability and withholding of information in Wuhan's outbreak.

\section{Public trust and voluntary cooperation}

The battle against COVID-19 necessitates keeping citizens informed and securing their voluntary participation (Fisher and Choe 2020). Information-sharing also protects the government from the risks of misinformation, rumors, and fake news. South Korean government learned the importance of providing accurate information to the public during the MERS outbreak, and how to gain public trust through transparency. South Korean officials initially withheld information about patients' locations and the names of hospitals treating MERS patients for fear of creating mass panic. With little information available, the public relied on a website created by a private citizen to track places visited by MERS patients and the names of hospitals (Oh 2020). The lack of communication from public health authorities resulted in fake MERS news and conspiracy theories, as well as shambolic cooperation between the national and local governments.

This time, as soon as COVID-19 emerged, the KCDC immediately activated its Office of Risk Communication. KCDC's director held daily briefings to provide public health guidelines, disclose information, and update the number of cases. Most Koreans considered daily briefings as the most reliable source of information, and its director Jung Eun-kyeong was often touted as a national hero. In addition, TV broadcasts, subway station public announcements, and smartphone text alerts reminded citizens to wear face masks 
and to keep social distancing, as well as provided regular updates of cases. The public health communication strategies during COVID-19 serve as an example of how to earn public trust during the pandemic - in this case, resulting in high public civic awareness and voluntary cooperation with authorities (Oh 2020).

\section{Mask diplomacy and resource-sharing}

Our second research question addresses how South Korea employed public diplomacy and nation branding in the COVID-19 context. One of the most common gestures of goodwill from any country's public diplomatic efforts is donation of material goods to other countries in crisis. In COVID-19, many countries experienced surging demand and shortage of medical equipment and personal protective equipment or PPE. South Korea, given its success at home with COVID-19, was able to ship millions of masks and medical supplies to other countries to help with their COVID-19 response. On May 11, South Korea donated two million medical face masks to the U.S., its closest ally, to help fill shortages in U.S. hospitals hit hardest by COVID-19 (Bowden 2020).

The U.S. is not the only focus of South Korea's mask diplomacy. Seoul also sent masks and medical supplies to other countries around the globe. In particular, South Korea applied a multi-pronged approach by framing some of its mask donations as part of commemoration of the 70th anniversary of the Korean War (1950-1953). Through this program, South Korea donated masks and other medical supplies to surviving veterans of the Korean War in more than 20 countries. On May 12, the U.S. Department of Veterans Affairs received 500,000 masks from South Korea, a gift that bolstered the department's imperiled supply reserves. In a statement, South Korea's Ministry of Patriots and Veterans Affairs said the donation is "to remember the noble sacrifice by the American veterans of the Korean War," adding that "[t]hese masks symbolize our countries' alliance and the appreciation of the Korean people who have never forgotten the American veterans' service and sacrifice-We are always grateful for them" (Shane III 2020). South Korea also donated 20,000 medical face masks to France to be distributed through the French Korean War Veterans Association.

Apart from medical masks, South Korea has been a reliable provider of COVID-19 test kits to countries around the world. On March 25, it was quick to announce that the country would provide COVID-19 testing kits to the U.S. The South Korean government, in a press release, said that President Donald Trump called to ask President Moon Jaein for help in sending tests kits and other medical equipment to the U.S. as it struggled with supply shortages (Fedschun
2020). The U.S. State Department later confirmed the phone conversation.

Another country that asked for South Korean aid was Colombia. The Andean country secured COVID-19 test kits, respirators, and other health supplies after a telephone call with Moon. Colombian President Ivan Duque, commenting on their conversation, in which he asked for Moon's assistance, said it was "a deeply emotional call" (Moss 2020). Duque shared with the news media how Moon recalled that 70 years ago, the Colombia Battalion served in the Korean War, and was the only Latin American contingent. Duque said that Moon expressed South Korea's great admiration and gratitude for Colombia, and promised that South Korea would support Colombia in its fight against COVID-19 (Moss 2020).

South Korea, showing a growing reputation - and nation brand-as a provider of high-quality COVID-19 test kits, received many requests from other countries to secure purchase or donations of South Korea-made test kits (Ferrier 2020). Aside from commercial sales, South Korean companies are also donating test kits to other countries, further adding to the country's positive image-building efforts (Ferrier and Hwang 2020). South Korean business conglomerates SK Energy and SK Trading International for instance donated 4000 Korean-made COVID-19 test kits to Myanmar in May (Yonhap 2020).

In April, the South Korean government and private companies sent donations of COVID-19 medical equipment, protective gear, and test kits to Indonesia. For over a decade, the two countries have maintained collaborative relationships since they began co-developing next-generation fighter planes and other defense projects. The South Korean government also pledged to provide a US\$500,000 in-kind grant to Indonesia to fight COVID-19 (Prasidya 2020).

Frustrated with the short supply of test kits, some state politicians in the U.S. have independently imported South Korean test kits, bypassing the White House, by using ties with South Korean officials and private individuals. Maryland Governor Larry Hogan managed to secure 500,000 South Korea-made tests. Hogan's success was due to his relationship with South Korea's ambassador to the U.S. Hogan's Korean-American wife also played a part (Ferrier 2020; Steinhauer 2020). Shortly after Maryland's success, U.S. Senator Cory Gardner announced that his home state of Colorado would buy 150,000 test kits from South Korea. Gardner noted that the procurement of test kits was made possible by his relationship with South Korea as chair of the Foreign Relations Subcommittee on East Asia (Boyd 2020; Wingerter 2020). Gardner said, "It first started out as my effort to build an economic national security relationship with Asia, has now turned into an incredible relationship to address COVID-19 health emergency" (Boyd 2020). Gardner prominently highlighted his role in procuring the test kits 
from South Korea in political TV ads for his 2020 Senate reelection campaign.

South Koreans' ability and willingness to send COVID19 test kits abroad not only translates into immediate commercial profits for South Korean companies but also enhances South Korea's nation brand, making it a win-win situation.

\section{Public-private collaboration: the Korean way}

Public-private sector collaboration has a long history in South Korea. South Korea's efforts to invigorate its cultural public diplomacy through public-private joint efforts can be traced to the mid-1990s when the government proposed a bold plan to launch South Korea's media entertainment industry by designating it as one of the country's key strategic export sectors (Kim 2018). As the country recovered from the Asian financial crises (1997-1998), the government sought to nurture the country's cultural entertainment industry as part of national economic reform and restructuring (Hong 2014). Subsidies and low-interest loans were given to music companies, cinema and drama productions, and computer game developers. Public sector support led to a rapid growth of the cultural entertainment industry, and accelerated the production of high-quality creations and exports of pop entertainment. Today, the popularity of the "Korean Wave" represented by K-pop, K-dramas, and K-movies has firmly established itself through enthusiastic fandom around the world, reinforcing the South Korean nation brand.

During the COVID-19 pandemic, this model of strong public-private sector collaboration is in full force again. The government speedily approved for emergency use COVID19 test kits made by private firms. At the peak of COVID19 in late February and early March, South Korea tested 20,000 people daily. Beyond fulfilling a domestic need, the government worked with test kit manufacturers to ramp up their production of test kits with global export and outreach in mind. As of June 2020, more than 30 South Korean firms are exporting COVID-19 test kits.

On March 25, 2020, Moon visited Seegene, one of Korea's leading manufacturers of biomedical equipment. Prior to Moon's visit, the KCDC had already given emergency approval to the test kits of Seegene and other companies. Instead of taking up to a year previously, emergency approval was acquired in a week, to quickly allow the test kits to be deployed by medical institutions and testing stations (Kirk 2020). In a speech during his visit, Moon promised the government would assist Seegene and other South Korean manufacturers in exporting COVID-19 test kits abroad. Less than a month later, on April 20, Seegene announced that it has exported 10 million COVID-19 test kits to more than 60 countries (Yoo 2020). Seegene's CEO reported that officials and diplomats from 45 countries sought to purchase his company's test kits (Cho and Lee 2020). To meet overseas demand, the government established a task force to provide online updates of supply and coordinated the exports of 30 South Korean biomedical firms manufacturing test kits. Just between March and April 2020, South Korean firms recorded an export volume of US\$132 million of COVID-19 test kits.

In an address to the nation on May 10, Moon thanked South Koreans for the country's collective success in coping with COVID-19, and expressed a desire to turn the global health crisis as a driving force for new opportunities in nation branding:

We have already become a country leading the world in epidemic prevention and control. Korea's COVID-19 response has become a global standard. The national status of Korea and the people's pride are higher than ever. All of this has been driven by the dedication of quarantine authorities and medical professionals, the willing participation of countless volunteers and the people who have demonstrated to the fullest a spirit of solidarity and cooperation... We will reinforce our epidemic prevention and quarantine systems further to become the undisputed number one epidemic response country leading the world (Moon 2020).

However, the nation branding efforts of the South Koreans did not stop at mask diplomacy, or donations of material goods such as masks, test kits, and other medical supplies.

\section{Beyond mask diplomacy}

South Korea's public diplomacy and nation branding strategies in the context of COVID-19 rely on the concept of mutual benefit, consistent with the collaborative aspects of resource-sharing with other countries. However, these resources are not confined to material resources such as masks and test kits, but also immaterial resources such as ideas, information, best practices, policies, and knowledge-elements that are equally important in public diplomacy and nation branding. For instance, on April 10, 2020, Microsoft co-founder and philanthropist Bill Gates called South Korea's practices and policies for tackling COVID19 specifically testing and digital contact tracing a global model. Gates, in a telephone call with Moon, tapping into South Korea's biomedical know-how, was keen to cooperate with South Korea on developing a COVID-19 vaccine (Shim 2020).

South Korea's COVID-19 ideas, policies, practices, and know-how extend beyond the medical. On April 15, 2020, the country held a national parliamentary election with the highest voter turnout (66.2\%) in three decades. Voters had their temperatures checked at polling station entrances, and were required to wear face masks and maintain social 
distancing while waiting in line to vote (Cheung 2020). Hand sanitizers and disposable gloves were also provided to voters (Delury 2020). The election, the world's first national election in the midst of the COVID-19 pandemic, is another public diplomacy and nation branding victory for South Korea.

South Korea's national election is noteworthy, conveying lessons on how a country can stay the course in the midst of the COVID-19 pandemic. Other countries have either canceled or delayed their elections due to the pandemic (Cheung 2020). For example, some U.S. states have delayed presidential primaries in 2020. France has suspended some local elections after COVID-19 cases began to surge, while Poland has delayed its presidential election (Poland to hold, 2020).

Moon's ruling Democratic Party and its affiliate party garnered a landslide win that gave him and his associates 180 seats in the 300-member National Parliament-the largest majority seats in three decades. Moon, struggling prior to COVID-19, has the pandemic to thank; South Korea's deft handling of the coronavirus pandemic helped him leverage his surging popularity and powered his ruling Democratic Party to victory (Choe 2020; Sharp 2020).

South Korea's election results offer a critical message to political leaders elsewhere: a political leader can win an election as long as citizens approve of his or her job performance during a public health crisis. In other words, prioritizing public health and producing stellar results, even in an economic downturn due to COVID-19, can pay off at the ballot box. South Korea's case presents a model for election during a pandemic. Singapore held its general election (due by April 2021) in July 2020; there was speculation that the move was inspired by South Korea's election success (Cheung 2020). New Zealand and Myanmar are also set to hold general elections in 2020, and Japan in 2021.

Due to South Korea's success with the COVID-19 pandemic, its major professional sports competitions started to return to action ahead of other countries'. On May 5, 2020, the Korea Baseball Organization commenced its new professional baseball season in three different cities. On May 8 , Korean professional soccer leagues also kicked off without stadium spectators. In the new baseball games, umpires wore protective masks, and cheerleaders danced beneath rows of unoccupied seats - covered with banners of printed images of fans-as players got back on the field (Keh 2020). South Korean baseball fans had to contend with watching the games via live television broadcast. So did American sports fans; on the same day, American sports channel ESPN started airing live broadcasts of South Korean baseball (Keh 2020).

The ideas, practices, policies, and knowledge discussed above are not without controversy. South Korea's reliance on digital contact tracing and personal records could be problematic. There have been some criticisms over possible infringement of privacy laws. However, most South Koreans prioritize public health outcomes over civil liberties and privacy concerns. The public overwhelmingly approve stringent legal and medical measures to protect human lives and safeguard their communities, and are highly critical of the occasional COVID-19 patient who recklessly puts other citizens at risk by refusing to cooperate with authorities (Kim 2020b).

For all the attention to South Korea's COVID-19 success, significant hurdles remain before other countries could adopt these ideas, practices, and policies. One is the political resolve of a government, whether to impose rigorous legal and medical measures. Another challenge is the public's will to cooperate with that government. Unlike South Korea, where citizens tend to have more trust in their government, many countries revealed a polarized and populist backlash during COVID-19 (Fisher and Choe 2020). What is clear is that South Korea has presented other countries with an alternative to top-heavy, Draconian travel restrictions and lockdowns.

\section{Sentiment analysis}

Our third and final research question investigates the outcomes of South Korea's efforts. From a public diplomacy perspective, was South Korea's COVID-19 diplomacy effective in helping the country "communicate with and attract the publics of other countries" (Nye 2008, p. 4) for nation branding? To understand international public sentiment about South Korea's COVID-19 mitigation efforts, we conducted a sentiment analysis of social media posts on Twitter and Instagram. A Social Studio analysis of 32,849 Englishlanguage posts from Twitter and Instagram users outside the country between January 20, 2020 (when COVID-19 was detected in South Korea) and June 10, 2020 on the topic of South Korea and COVID-19 shows an overwhelmingly positive sentiments, with $89.4 \%$ positive posts, suggesting a favorable nation brand for South Korea. We concede that the pandemic is far from over but our period of analysis, up to June 10, 2020 and spanning nearly six months, is sufficient for shedding light on how South Korea's efforts are viewed by international audiences.

Countries also pay significant attention to how their nation brands are portrayed in the international news media. Case in point: Singapore. Early on, Singapore was praised as a shining example and a "gold standard" in how to handle COVID-19, earning accolades from the WHO and influential international news media including the New York Times, and Forbes for the country's swift response, aggressive contact tracing and testing, and decisive leadership (Barron 2020; Warrell 2020). Through the beginning of April 2020, Singapore recorded fewer than 600 cases 
and its economy remained open. On March 23, Singapore Prime Minister Lee Hsien Loong appeared on CNN's GPS for an exclusive interview with host Fareed Zakaria. Lee described how his country has responded successfully to COVID-19. Zakaria noted that Singapore has earned wide praise for taking swift and targeted action, and they discussed what lessons other countries could learn from Singapore. However, the tide quickly turned-and along with it, the international news media's assessment of Singapore's COVID-19 efforts. By the end of April, the number of cases surged to more than 17,000 due to outbreaks among its migrant workers in crowded dormitories, and a lockdown had to be imposed, unleashing a series of negative news stories (Beaubien 2020; Cai and Lai 2020; Carroll 2020; Griffiths 2020; Jaipragas 2020; Stack 2020; Yeung and Yee 2020). Reacting to a critical New York Times magazine essay about the surge in cases among Singapore's migrant workers, Singapore's ambassador to the U.S. wrote to the newspaper on June 2 to defend the citystate's response (Mirpuri 2020).

To assess the international media's perception of South Korea's COVID-19 diplomacy, we conducted a textual analysis of English-language media reports published outside the country. We used Leximancer, a text-mining software that scientometrically describes and analyzes content of collections of textual documents to conduct a sentiment analysis, to extract subjectivity in the texts to measure "the attitude of a speaker or writer towards a concept, whether they express something positively or negatively" (Ward et al. 2014). Sentiment refers to subjective feelings, rather than facts, and includes people's attitude, emotions, and opinions (Mullen 2017). Sentiment analysis has been used in many studies including public perception of Singapore's hosting of the Trump-Kim Summit (Kim and Lee 2020); customer reviews of hotels, restaurants, and cruises (Ma et al. 2018), and public perceptions of the homestay initiative for asylum seekers in Australia (Hebbani and Angus 2016).

Based on the period of analysis of January 20 through June 10, 2020, our search generated 8318 English-language texts comprising 6559 news articles, 1156 broadcast news transcripts, 242 blogs, 156 trade publication articles, 128 magazine articles, and 77 newsletter items worldwide that focused on South Korea's COVID-19 response. A sentiment analysis of the 8318 texts showed an overwhelming representation of positive sentiments about South Korea's COVID-19 efforts with $96 \%$ of texts showing positive mentions.

In Leximancer, a concept is a group of related words that travel together in the text. Evidence words include synonyms and adjectives. Leximancer concepts begin with seed words. The learning process then evolves the seed-word definitions into a full thesaurus that generate concepts that are wordlike or name-like (proper names such as John or Australia).
The overall likelihood scores in Leximancer indicate positive sentiments. "South Korea" was the positive concept with the highest likelihood score at 97\%. Likelihood scores describe the conditional probability of text segments within a concept also containing another concept (Leximancer 2011), meaning that $97 \%$ of text segments with "South Korea" contained positive sentiments. Other prominent positive concepts include "testing" (94\%), "tracing" (92\%), "model" (91\%), technology (90\%), lessons $(89 \%)$, "culture" (86\%), "isolation" $(85 \%)$, "trust in the government" (82\%), "aid to other countries" (80\%), and "mask-wearing (76\%). Only four elements were reported negatively. "China" was the negative concept in Leximancer with the highest likelihood score at $24 \%$, meaning that $24 \%$ of the text segments with the term "China" contained negative sentiments. Another negative concept was "United States," with a likelihood score at $19 \%$, followed by Italy (18\%) and the U.K (12\%). Taken as a whole, the overall likelihood scores of all concepts (see Table 1) indicate that international news media were favorable toward South Korea, especially when considering that the four negative elements represent other nation-states.

Overall, our findings, based on sentiment analysis of social media and international news media, suggest a positive nation brand for South Korea in the context of COVID-19. They support the assertions that the COVID19 pandemic has led to an improvement in South Korea's global image, and that the country is perceived by others as a global health leader and a model on how to cope with COVID-19 (Attias 2020; Chung and Soh 2020; Thompson 2020; Oh 2020).

Table 1 Likelihood scores of each leximancer concept

\begin{tabular}{llll}
\hline Concept & $\begin{array}{l}\text { Positive } \\
\text { likelihood } \\
(\%)\end{array}$ & Concept & $\begin{array}{l}\text { Negative } \\
\text { likelihood } \\
(\%)\end{array}$ \\
\hline South Korea & 97 & China & 24 \\
Testing & 94 & United States & 19 \\
Tracing & 92 & Italy & 18 \\
Model & 91 & UK & 12 \\
Technology & 90 & & \\
Lessons & 89 & & \\
Culture & 86 & & \\
Isolation & 85 & & \\
Trust in the government & 82 & & \\
Aid to other countries & 80 & & \\
Mask-wearing & 76 & & \\
\hline
\end{tabular}




\section{Explicating pandemic public diplomacy}

Our study contributes to the literature in public diplomacy and nation branding in a number of ways. As far as we know, ours is the first study to address the interplay between public diplomacy and nation branding in the COVID-19 era. Based on a case study, we explicated South Korea's COVID-19 response and its public diplomacy and nation branding campaign to enhance its standing on the world stage through sharing and transmission of material resources (medical supplies) as well as immaterial resources (ideas, information, best practices, policies, and knowledge) it has produced for and learned in its response to COVID-19.

A conceptual explication of pandemic public diplomacy does not yet exist. The loose term of "pandemic diplomacy" and its variants "COVID-19 diplomacy" and "coronavirus diplomacy" are found in the COVID-19 discourse featured in news media reports and trade publications. Using a keyword search, we found 46 blogs and articles that included pieces from the Council on Foreign Relations (www.cfr.org), foreignpolicy.com, and news outlets such as the New York Times, Hanoi Times, and Global Times (www.globaltimes.cn). However, the conceptual scope of pandemic public diplomacy as applied in that discourse is limited, referring to the deployment of aid such as masks (Bier and Arceneaux 2020; Horton 2020; Jao 2020; McLaughlin 2020; Li and McElveen 2020; Wang 2020), to the extent that "pandemic diplomacy" and its variants were used interchangeably with "mask diplomacy" in the popular press.

To address the gap, we offer an exploratory conceptual explication of pandemic public diplomacy (PPD) that is grounded in a normative framework of substance, information, trust, collaboration, and mutual benefit. PPD refers to state-initiated efforts involving non-state actors and networks aimed at communicating with foreign publics in a health pandemic context through sharing and transmission of material and immaterial resources to mitigate the health threat, foster a positive nation brand, and contribute to a healthful global environment.

The five concepts are demonstrated in varying degree in South Korea's case. Pandemic public diplomacy demands substance. As argued by Anholt (2010), "[n]ational reputation cannot be constructed, it can only be earned" (p. 6). Suggesting that "action speaks louder than words" (p. 10), Anholt is critical of what he sees as an overemphasis on logos and slogans in nation branding. Communication or marketing campaigns alone-or words-are no substitute for practices, policies and accomplishment because "that altering the image of a country or city may require something a little more substantial than graphic design, advertising or PR campaigns" (p. 9). An implication for PPD is that a nation cannot brand itself well unless it demonstrates an ability to contain the pandemic. Track record matters; action does speak louder than words. In a pandemic, public diplomacy "is not merely a performative act" and "least of all pretentions or ideological grandstanding for political expediency" (Wang 2020). As a media-connected world watches, a country's national reputation and credibility are on the line and can easily suffer real and permanent damage if its leaders do not deliver. Nation brand comparison is not confined to external publics only; internally too, there is potential for significant damage because citizens could compare how their countries (and leaders) perform relative to other countries in COVID-19 response. After all, a country's internal publics are another country's external publics.

Global pandemics are information-deficient environment with missing or incomplete information. As fear and uncertainty reign, PPD should focus not only on material resources such as masks, test kits, and ventilators but more importantly immaterial resources such as information with the goal of inspiring trust and confidence, as seen in South Korea's case, especially in a new media landscape fractured, politicized, and weighed down by social media cacophony.

Pandemics tend to drive people apart rather than bring them together, but PPD is necessarily collaborative. It can serve "to provide collective linkages between national selfinterest and international good" (Wang 2020). In non-pandemic situations, public diplomacy and nation branding tend to focus on one-upmanship, but when confronted by a common enemy such as COVID-19 and bound by a shared crisis mentality and a fundamental human instinct for well-being and survival, the tension between competition and collaboration is less acute.

Finally, the end goal of PPD must also rest on mutual benefit-as seen in tangible outcomes that nation-states can reap by sharing ideas, information, best practices, and policies, and knowledge as well as medical supplies-in the global battle against COVID-19. In a world of interdependency and hyperconnected international travel where isolation and permanent border shutdowns are not sustainable, national selfinterest is intertwined with international good. In a global crisis of such a magnitude, countries and their leaders must avoid national selfishness. To borrow the analogy used by U.S. President Franklin D. Roosevelt in the Lend Lease Act, you should lend your neighbor your garden hose if his house was on fire and thereby keeping the fire from spreading to your house.

In the COVID-19 era, a nation's ability to project positive influence and manage its nation brand ultimately hinges on how it has responded to the crisis-as seen in South Korea's case. As COVID-19 challenges institutions, communities, and individuals across the globe, it is turning into "a test 
case of a nation's public diplomacy resolve and capability" (Wang 2020). Under the specter of COVID-19, major powers such as the U.S., Japan, China, Russia, and the EU appeared to have faltered in their response so far. Even an influential middle power like Singapore, well known for its sophisticated public diplomacy machinery and robust image, has struggled to manage its nation brand vis-à-vis COVID-19. By forcing a reconstruction of global priorities, institutional mandates and national agendas, this novel coronavirus will continue to re-shape a new public diplomacy order, requiring swift, decisive, and dramatic shifts in response from nationstates including the transmission of ideas, information, best practices and policies based on values of trust, collaboration, mutual benefit, and international good.

\section{Compliance with ethical standards}

Conflict of interest On behalf of all authors, the corresponding author states that there is no conflict of interest.

\section{References}

Anholt, S. 2007. Competitive identity: The new brand management for nations, cities, regions. Basingstoke, UK: Palgrave Macmillan.

Anholt, S. 2010. Places: Identity, image, and reputation. New York: Palgrave Macmillan.

Asia Pacific Observatory on Health Systems and Policies. n.d. Republic of Korea health system review. https://www.searo.who.int/entity/ asia_pacific_observatory/publications/hits/hit_korea/en/

Attias, S. 2020. Asian soft power grows in the coronavirus era. https:// besacenter.org/perspectives-papers/coronavirus-asia-soft-power/

Avraham, E. 2009. Marketing and managing nation branding during prolonged crisis: The case of Israel. Place Branding and Public Diplomacy 5 (3): 202-212.

Avraham, E. 2016. Destination marketing and image repair during tourism crises: The case of Egypt. Journal of Hospitality and Tourism Management 28: 41-48.

Avraham, E. 2018. Nation branding and marketing strategies for combatting tourism crises and stereotypes toward destinations. Journal of Business Research. https://iranarze.ir/wp-content/uploa ds/2018/07/E8345-IranArze.pdf

Barron, L. 2020. What we can learn from Singapore, Taiwan and Hong Kong about handling coronavirus. Time, March 13.https://time. com/5802293/coronavirus-covid19-singapore-hong-kong-taiwa $\mathrm{n} /$

Beaubien, J. 2020. Singapore was a shining star in COVID-19 control-until it wasn't. NPR, May 3. https://www.npr.org/sections/ goatsandsoda/2020/05/03/849135036/singapore-was-a-shiningstar-in-covid-control-until-it-wasnt

Bier, L.M., and P.C. Arceneaux. 2020. Vietnam's "underdog" public diplomacy in the era of COVID-19 pandemic. USC Center on Public Diplomacy, April 23. https://www.uscpublicdiplom acy.org/blog/vietnam\%E2\%80\%99s-\%E2\%80\%9Cunderdog $\% \mathrm{E} 2 \% 80 \% 9 \mathrm{D}$-public-diplomacy-era-covid-19-pandemic

Bowden, J. 2020. South Korea sends $2 \mathrm{~m}$ masks to US to fight coronavirus. The Hill, May 10. https://thehill.com/policy/internatio nal/497055-south-korea-sends-2m-masks-to-us-to-fight-coron avirus-seoul
Boyd, S. 2020. Colorado scores 150,000 coronavirus tests with the help of Sen. Cory Gardner. CBS4 Denver, April 23. https://denve r.cbslocal.com/2020/04/23/coronavirus-cory-gardner-coloradotests-south-korea/

Cai, W., and R.K.K. Lai. 2020. Packed with migrant workers, dormitories fuel coronavirus in Singapore, April 28. https://www.nytim es.com/interactive/2020/04/28/world/asia/coronavirus-singaporemigrants.html

Cai, P., P.T. Lee, and A. Pang. 2009. Managing a nation's image during crisis: A study of the Chinese government's image repair efforts in the "Made in China" controversy. Public Relations Review 35 (3): 213-218.

Carlsen, B., and C. Glenton. 2016. The swine flu vaccine, public attitudes, and researcher interpretations: a systematic review of qualitative research. BMC Health Services Research 16 (1): 203.

Carroll, A.E. 2020. Lessons from Singapore: Why we may need to think bigger, April 14. https://www.nytimes.com/2020/04/14/ upshot/coronavirus-singapore-thinking-big.html.

Cheung, R. 2020. Election during a pandemic: Can Singapore replicate South Korea's model? AsiaOne, April 16. https://www.asiao ne.com/singapore/election-during-pandemic-can-singapore-repli cate-south-koreas-model.

Cho, J.H., and H.K. Lee. 2020. South Korea's coronavirus test makers in high demand. ABC News, April 4. https://abcnews.go.com/ International/south-koreas-coronavirus-test-makers-high-deman d/story?id=69958217.

Choe, S.H. 2020. In South Korea vote, virus delivers landslide win to governing party. The New York Times, April 15. https://www. nytimes.com/2020/04/15/world/asia/south-korea-election. $\mathrm{html}$ ?auth $=\operatorname{login}=$ email\&login $=$ email

Cohen, E. 2020. Prestigious scientific panel tells White House coronavirus won't go away with warmer weather. $C N N$, April 9.https ://www.cnn.com/2020/04/08/health/coronavirus-stays-warme r-weather/index.html.

COVID-19 Pandemic. (n.d.). World Health Organization. Retrieved from https://www.who.int/emergencies/diseases/novel-coron avirus-2019

Cowling, B.J., and W.W. Lim. 2020. They've contained the virus. Here's how. New York Times, March 13. https://nytimes.com/ coronavirus-best-response.html

Chua, A.A., and A. Pang. 2012. US government efforts to repair its image after the 2008 financial crisis. Public Relations Review 38 (1): 150-152.

Chung, D., and S.H. Soh. 2020. Korea's response to COVID-19: Early lessons in tackling the pandemic, March 23. https://blogs.world bank.org/eastasiapacific/koreas-response-covid-19-early-lesso ns-tackling-pandemic

Daily briefing 6/6. 2020. The Korea Centers for Disease Control and Prevention, June 6. https://www.cdc.go.kr/board/board .es? $\mathrm{mid}=\mathrm{a} 20501000000 \& \mathrm{bid}=0015$

Delury, J. 2020. How democracy won the world's first coronavirus election. The New York Times, April 16. https://www.nytim es.com/2020/04/16/opinion/south-korea-election-coronaviru s.html?searchResultPosition $=3$

Dinnie, K. 2008. Nation branding: Concepts, issues, practice. Oxford, United Kingdom: Butterworth-Heinemann.

Fan, Y. 2006. Banding the nation: What is being branded? Journal of Vacation Marketing 12 (1): 5-14.

Fan, Y. 2010. Branding the nation: Towards a better understanding. Place Branding and Public Diplomacy 6 (2): 97-103.

Fedschun, T. 2020. Coronavirus testing kits to be provided by South Korea after Trump call. Fox News, March 25. https://www.foxne ws.com/world/coronavirus-testing-kits-south-korea-trump-call

Ferrier, K. 2020. South Korean ramps-up exports of COVID-19 testing kits. The Diplomat, April 9. https://thediplomat.com/2020/04/ south-korea-ramps-up-exports-of-covid-19-testing-kits/ 
Ferrier, K., and S. Hwang. 2020. How South Korea is building influence through COVID-19 testing kits. The Diplomat, April 30. https://thediplomat.com/2020/04/how-south-korea-is-buildinginfluence-through-covid-19-testing-kits/

Fisher, M., and S.H. Choe. 2020. How South Korea flattened the curve. The New York Times, April 10. https://www.nytim es.com/2020/03/23/world/asia/coronavirus-south-korea-flattencurve.html?searchResultPosition $=1$

476 additional cases are confirmed. 2020. Korea Centers for Disease Control and Prevention, March 2. https://www.cdc.go.kr/board .es? $\mathrm{mid}=\mathrm{a} 20501000000 \& \mathrm{bid}=0015 \& \mathrm{act}=$ view\&list_no $=36641$ 7.

Freedman, L. 2020. The real reason the UK government pursued "herd immunity" - and why it was abandoned. New Statesman, April 1. https://www.newstatesman.com/politics/uk/2020/04/real-reaso n-uk-government-pursued-herd-immunity-and-why-it-was-aband oned.

Germany retains top "nation brand" ranking. 2019. Ipsos, November 18. https://www.ipsos.com/en-us/news-polls/Germany-Retai ns-Top.

Gilboa, E. 2009. The public diplomacy of middle powers. Public Diplomacy Magazine 1 (2): 22-28.

Gomez, E.J. 2014. Cuba's health diplomacy in the age of Ebola. $B B C$, November 14.https://www.bbc.com/news/world-latin-ameri ca-29984688.

Griffiths, J. 2020. Singapore had a model coronavirus response, then cases spiked. What happened? CNN, April 19. https://www.cnn. com/2020/04/18/asia/singapore-coronavirus-response-intl-hnk/ index.html

Groll, E. 2013. Cuba's great export? Medical diplomacy. Foreign Policy, May 7.https://foreignpolicy.com/2013/05/07/cubas-greatestexport-medical-diplomacy/

Harling, K. 2012. An overview of case study. SSRN. Retrieved from: https://ssrn.com/abstract=2141476 or https://doi.org/10.2139/ ssrn.2141476

Harrison, H., Birks, M., Franklin, R., and J. Mills. 2017. Case study research: Foundations and methodological orientations. Qualitative Social Research, January. https://www.qualitative-research. net/index.php/fqs/article/view/2655.

Hebbani, A., and D. Angus. 2016. Charity begins at home: Public perceptions of the homestay initiative for asylum seekers in Australia. Australian Journalism Review 38 (1): 83.

Hong, E. 2014. The birth of Korean cool: How one nation is conquering the world through pop culture. New York: Picador.

Horton, C. 2020. Taiwan counters China's isolation campaign with mask diplomacy. Nikkei Asian Review, April 23. https://asia. nikkei.com/Politics/International-relations/Taiwan-countersChina-s-isolation-campaign-with-mask-diplomacy

Jaipragas, B. 2020. 'Cut back on the back-patting': Singapore's coronavirus response loses its shine as critics speak out. The South China Morning Post, April 10. https://www.scmp.com/weekasia/health-environment/article/3079451/cut-back-back-patti ng-singapores-coronavirus-response

Jao, N. 2020. Mask Diplomacy' a Boost for Taiwan. Foreign Policy, April 13. https://foreignpolicy.com/2020/04/13/taiwan-coron avirus-pandemic-mask-soft-power-diplomacy/

Johansson, R. 2003. Case study methodology, in International Conference on Methodologies in Housing Research, Stockholm.

Kang, H. 2008. Simon Anholt on brand Korea. Nation-Branding, September 3. https://nation-branding.info/2008/09/03/brand-korea/

Keh, A. 2020. Watching South Korean baseball on TV? Let us help. The New York Times, May 5. https://www.nytimes.com/2020/05/05/ sports/baseball/coronavirus-baseball-korea-opening.html

Ketter, E. 2016. Destination image restoration on Facebook: The case study of Nepal's Gurkha Earthquake. Journal of Hospitality and Tourism Management 28: 66-72.
Kim, H.S. 2018. When public diplomacy faces trade barriers and diplomatic frictions: The case of the Korean Wave. Place Branding and Public Diplomacy 14: 234-244.

Kim, H.S. 2017. The Korean Wave as soft power public diplomacy. In The Routledge handbook of soft power, ed. N. Chitty, J. Li, G. Rawnsley, and C. Hayden, 414-424. New York: Routledge.

Kim, H.S., and S.T. Lee. 2020. Peace talks: Public diplomacy and place branding in the 2018 Trump-Kim summit in Singapore. Place Branding and Public Diplomacy. https://doi. org/10.1057/s41254-020-00163-6.

Kim, H. 2020. The sociopolitical context of the COVID-19 response in South Korea. BMJ Global Health 5 (5): e002714.

Kim, M. 2020b. How South Korea stopped Covid-19 early. The ASPI Strategist, April 28. https://www.aspistrategist.org.au/howsouth-korea-stopped-covid-19-early/.

Kirk, D. 2020. Korea races to export test kits after Trump asks Moon for help fighting COVID-19. Forbes, March 27. https://www. forbes.com/sites/donaldkirk/2020/03/27/korea-races-to-expor t-test-kits-after-trump-asks-moon-for-help-fighting-covid -19/\#5c701ce11244.

Lancaster, K., and M. Rubin. 2020. Assessing the early response to Beijing's pandemic diplomacy. Council on Foreign Relations, April 30. https://www.cfr.org/blog/assessing-early-responsebeijings-pandemic-diplomacy

Lancaster, K., Rubin, M., and M. Rapp-Hooper. 2020. Mapping China's health silk road. Council on Foreign Relations, April 10. https://www.cfr.org/blog/mapping-chinas-health-silk-road

Lee, S.T., and I. Basnyat. 2013. From press release to news: mapping the framing of the $2009 \mathrm{H} 1 \mathrm{~N} 1 \mathrm{~A}$ influenza pandemic. Health Communication 28 (2): 119-132.

Leximancer. 2011. Leximancer manual version 4. www.lexim ancer.com/site-media/lm/science/Leximancer_Manual_Versi on_4_0.pdf

Li, C., and R. McElveen. 2020. Mask diplomacy: How coronavirus upended generations of China-Japan antagonism, March 9. https://www.bookings.edu/blog/order-from-chaos/2020/03/09/ mask-diplomacy-how-coronavirus-upended-generations-ofchina-japan-antagonism/.

Ma, E., M. Cheng, and A. Hsiao. 2018. Sentiment analysis: A review and agenda for future research in hospitality contexts. International Journal of Contemporary Hospitality Management 30 (11): 3287-3308.

Martin, T. 2020. East vs. West: Coronavirus fight tests divergent strategies. The Wall Street Journal, March 13. https://www. wsj.com/articles/east-vs-west-coronavirus-fight-tests-diver gent-strategies-11584110308.

McLaughlin, T. 2020. Is this Taiwan's moment? The Atlantic, May 16. https://www.theatlantic.com/international/archive/2020/05/ taiwan-china-who-coronavirus-pandemic/611737/.

MERS outbreak in the Republic of Korea 2015. n.d. World Health Organization. https://www.who.int/westernpacific/emergencie s/2015-mers-outbreak.

Mirpuri, A. 2020. Singapore defends its coronavirus response. The New York Times, June 2. https://www.nytimes.com/2020/06/02/ magazine/singapore-defends-coronavirus-response.

Moon, J. 2020. Special address to the nation. The Korea Herald, May 10. https://www.koreaherald.com/view.php?ud=20200 510000126.

Moss, L. 2020. South Korea to donate respirators, medical equipment, expertise to Colombia. Finance Colombia, April 3. https ://www.financecolombia.com/south-korea-to-donate-respirator s-medical-equipment-expertise-to-colombia/.

Nation Brands 100. 2019. 2019 Ranking. https://brandirectory.com/ rankings/nation-brands/table. 
McNeil, D.G., \& Jacobs, A. 2020. Blaming China for pandemic, Trump says U.S. will leave the WHO. New York Times, May 29. https:// www.nytimes.com/2020/05/29/health/virus-who.html.

Mullen, T. 2017. Introduction to sentiment analysis. https://lct-maste r.org/files/MullenSentimentCourseSlides.pdf.

Nye, J. 2008. Public diplomacy and soft power. Annals of the American Academy of Political and Social Science 616 (1): 94-109.

Oh, S.Y. 2020. South Korea's success against COVID-19. The Regulatory Review, May 14. https://www.theregreview.org/2020/05/14/ oh-south-korea-success-against-covid-19/.

142 additional cases are confirmed. 2020. Korea Centers for Disease Control and Prevention, March 2. https://wwwcdc.go.kr/board .es $? \mathrm{mid}=\mathrm{a} 20501000000 \& \mathrm{bid}=0015 \&$ act $=$ view\&list_no $=36629$ 5.

Poland to hold presidential election on June 28, after delay due to Covid-19. n.d. France 24.https://www.france24.com/en/20200 603-poland-to-hold-presidential-election-on-june-28-after-delay -due-to-covid-19.

Potter, E. 2018. The evolving complementarity of nation-branding and public diplomacy: projecting the Canada brand through "weibo diplomacy" in China. Canadian Foreign Policy Journal 24 (2): 223-237.

Prasidya, Y. 2020. Emergency aid from South Korea reaches viruscrippled Indonesia. Jakarta Post.https://www.thejakartapost. com/news/2020/04/16/emergency-aid-from-south-korea-reach es-virus-crippled-indonesia.html.

Quelch, J., and K. Jocz. 2004. Positioning the nation-state. Place Branding 1 (1): 74-79.

Rasmussen, R.K., and H. Merkelsen. 2014. The risks of nation branding as crisis response: A case study of how the Danish government turned the Cartoon Crisis into a struggle with Globalization. Place Branding and Public Diplomacy 10 (3): 230-248.

Rockower, P.S. 2012. Recipes for gastrodiplomacy. Place Branding and Public Diplomacy 8: 235-246.

Scott, N., Ashton, A. S., Ding, P., \& Xu, H. 2011. Tourism branding and nation building in China. International Journal of Culture, Tourism and Hospitality Research.

Sharp, A. 2020. South Korean landslide changes Japan and Singapore election math. Nikkei Asian Review, April 24. https://asia.nikke i.com/Politics/South-Korean-landslide-changes-Japan-and-Singa pore-election-math.

Shim, E. 2020. Bill Gates agrees to cooperate with South Kora on COVID-19 vaccine. UPI, April 10.https://www.upi.com/Top_ News/World-News/2020/04/10/Bill-Gates-agrees-to-cooperatewith-South-Korea-on-COVID-19-vaccine/1211586531660/.

Singh, J.P., and S. Macdonald. 2017. Soft power today: measuring the influences and effects. Edinburgh: The Institute for International Cultural Relations, The University of Edinburgh.

Snyder, A., and M. Sindyukov. 2020. How COVID-19 is changing the soft power game. Diplomatic Courier. The Diplomatic Courier. https://www.diplomaticourier.com/posts/how-covid-19-is-chang ing-the-soft-power-game.

Soft Power 30 Index. 2019. South Korea. https://softpower30.com/ country/south-korea/.

Stack, M.K. 2020. A sudden coronavirus surge brought out Singapore's dark side. The New York Times, May 20. https://www. nytimes.com/2020/05/20/magazine/singapore-coronavirus.html.

Stake, R.E. 1995. The art of case study research. USA: Sage Publications.

Steinhauer, J. 2020. Frustrated by lack of coronavirus tests, Maryland got 500,000 from South Korea. The New York Times, April 20. https://www.nytimes.com/2020/04/20/us/larry-hogan-wife-yumikorea-coronavirus-tests.html.

Szondi, G. 2008. Public diplomacy and nation branding: Conceptual similarities and differences. Clingendael: Netherlands Institute of International Relations.
Thompson. 2020. What's behind South Korea's COVID-19 exceptionalism? The Atlantic.https://www.theatlantic.com/ideas/archi ve/2020/05/whats-south-koreas-secret/611215/.

U.S. says 'significant evidence coronavirus came from China lab.' 2020. Al-Jazeera, May 3. https://www.aljazeera.com/ news/2020/05/trump-threatens-action-china-covid-19-20050 3101120358.html.

Vaughan, E., and T. Tinker. 2009. Effective health risk communication about pandemic influenza for vulnerable populations. American Journal of Public Health 99: S324-S332.

Vaxevanidou, M. 2016. Public diplomacy as a tool to change the image of a country in crisis. Journal of Media Critiques 2 (8): 111-120.

Vaxevanidou, M. 2017. Nation rebranding in a period of crisis and the role of public diplomacy: The case study of Greece. Journal of Media Critiques 3 (11): 57-71.

Volcic, Z., and M. Andrejevic. 2011. Nation branding in the era of commercial nationalism. International Journal of Communication 5: 598-618.

Wang, J. 2020, March 18. Public diplomacy in the age of pandemics. USC Center on Public Diplomacy. https://www.uscpublicdiplom acy.org/blog/public-diplomacy-age-pandemics

Ward, V., R. West, S. Smith, S. McDermott, J. Keen, R. Pawson, and A. House. 2014. The role of informal networks in creating knowledge among health-care managers: a prospective case study. Health Services and Delivery Research. https://doi.org/10.3310/ hsdr02120.

Wingerter, J. 2020. 100,000 coronavirus tests expected at Denver airport in the coming days. The Denver Post, March 20. https:// www.denverpost.com/2020/03/20/coronavirus-tests-coloradoaytu-cory-gardner/.

Warrell, M. 2020. COVID-19 leadership lessons from Singapore: Be ready, be bold, be decisive. Forbes, March 30. https://www.forbe s.com/sites/margiewarrell/2020/03/30/singapore-sets-gold-stand ard-against-covid-19-be-ready-be-decisive-be-bold/\#7359fd3f7a 22

Yeung, J., and I. Yee. 2020. Tens of thousands of Singapore's migrant workers are infected. The rest are stuck in their dorms as the country opens up. CNN, May 14. https://www.cnn. com/2020/05/14/asia/singapore-migrant-worker-coronaviru s-intl-hnk/index.html.

Yin, R. 1984. Case study research: Design and methods, 1st ed. Newbury Park: Sage.

Yin, R. 2002. Case study research: Design and methods, 3rd ed. Thousand Oaks: Sage.

Yin, R. 2014. Case study research: Design and methods, 5th ed. Thousand Oaks: Sage.

Yonhap. 2020. SK Innovation's two affiliates donate 4,000 COVID-19 test kits to Myanmar. The Korea Herald, May 10. https://www. koreaherald.com/view.php?ud=20200510000221.

Yoo, J.H. 2020. Seegene exports 10 million COVID-19 test kits overseas. Chosun Ilbo, April 21. https://news.chosun.com/site/data/ html_rer/2020/04/21/202004210045.html?utm_source=naver \&utm_medium=original\&utm_campaign=news.

Publisher's Note Springer Nature remains neutral with regard to jurisdictional claims in published maps and institutional affiliations.

Seow Ting Lee is professor of strategic communication and health communication in the Department of Advertising, Public Relations and Media Design at the University of Colorado in Boulder. Her research has been published in leading, peer-reviewed journals in the field including Journal of Communication, Public Relations Review, Journal of Public Relations Research, Journal of Health Communication, Health Communication, Media Culture and Society, Mass 
Communication and Society, Health Promotion International, and Journal of Mass Media Ethics.

Hun Shik Kim is an associate professor in the Department of Journalism at the University of Colorado in Boulder. His teaching and research interests include broadcast journalism, telecommunication systems and policies, international communication, and war and conflict reporting. Dr. Kim's research has been published in numerous journals, and he is author of two books on global television industry and war reporting. Before joining CU Boulder, he was a network television reporter and news producer for the Korean Broadcasting System (KBS) in Seoul. 